\title{
Improving wastewater mixing and oxygenation efficiency with solar-powered circulation
}

\author{
H. Kenneth Hudnell • David Green • \\ Ron Vien · Scott Butler • Greg Rahe • \\ Bruce A. Richards $\cdot$ Joel Bleth
}

Received: 28 July 2010/Accepted: 21 December 2010/Published online: 11 January 2011

(C) The Author(s) 2011. This article is published with open access at Springerlink.com

\begin{abstract}
Electrical grid-powered aeration is used in most pond-based systems and equalization basins at activated sludge wastewater treatment plants to provide the mixing and oxygenation that enables bacteria to digest organicmatter. Oxygen also is needed in the near-surface water of all ponds and basins to provide an "odor cap" by oxidizing malodorous sulfur compounds, preventing their release to air. Much more aeration typically is needed to mix than oxygenate the wastewater. This imbalance causes an operational inefficiency in that grid-power is used to supply more oxygen than needed. The U.S. Environmental
\end{abstract}

\section{H. K. Hudnell ( $\square)$}

University of North Carolina at Chapel Hill, Institute for the Environment; SolarBee, Inc., 105 Serrano Way, Chapel Hill, NC 27517, USA

e-mail: kenhud@SolarBee.com

D. Green

Public Works Department, City of Rochester, 45 Old Dover

Road, Rochester, NH 03867, USA

R. Vien

Pittsfield Water Department, 127 South Main Street, Pittsfield, NH 03263, USA

S. Butler

Water and Sewer Division, Town of Exeter, 13 Newfields Road, Exeter, NH 03833, USA

\section{G. Rahe}

Engineering Department, Public Service of New Hampshire, PO Box 330, Manchester, NH 03105, USA

B. A. Richards

SolarBee, Inc., 143 Madison Drive, Newark, DE 19711, USA

J. Bleth

SolarBee, Inc., Headquarters, 3225 Highway 22, Dickinson, ND 58601, USA
Protection Agency concluded that the use of solar-powered circulation (SPC) technology reduces the need to aerate, operational costs, and greenhouse gas emissions associated with electrical power generation. However, the Agency did not quantify electrical, water quality, or other parameters. The New Hampshire Department of Environmental Services directed a 3-site study to quantify the ability of SPC to replace some or all aeration while maintaining good effluent water quality. Water quantity and quality, odor event, and kilowatt-hour consumption and expenditure data were collected 1 year prior to, and 2 years during, SPC treatment at pond-based treatment plants in Pittsfield and Exeter, and at the activated sludge treatment plant in Rochester. Final effluent water quality was maintained, no effluent violations or odor events occurred, and sludge buildup was minimal during the SPC study period. Electricity usage and costs declined by about $38 \%$ in Pittsfield and Exeter, and by about $87 \%$ in Rochester, resulting in carbon dioxide emission reductions of 273,161, 918,183, and 1,082,509 kg, respectively. Payback periods ranged from 1.9 to 3.7 years. SPC improved operational efficiency at the plants by reducing grid-power consumption while operational objectives were met. The 25-year expected lifetime of SPC units with minimal maintenance requirements indicated long-term reductions in operational expenses and greenhouse gas emissions.

Keywords Wastewater - Aeration - Circulation - Mixing · Oxygen $\cdot$ Solar-powered circulation

\section{Introduction}

Electrical grid-powered aeration is used in most municipal and industrial wastewater treatment plant (WWTP) ponds to both mix and oxygenate wastewater (10 State Standards 
1997). Mixing and oxygenating wastewater in pond-based systems and equalization basins at activated sludge treatment plants suspends organic solids and enables aerobic digestion by bacteria. Oxygen also is needed in the nearsurface water of all ponds and basins to provide an "odor cap" by oxidizing malodorous sulfur compounds, preventing their release to air. However, much more aeration typically is needed to mix than oxygenate the wastewater. This imbalance creates an operational inefficiency; the use of aerators to intensively mix the wastewater supplies much more dissolved oxygen (DO) than the aerobic bacteria can consume. The excessive use of aeration at WWTPs increases grid-power consumption and associated greenhouse gas emissions, as well as operational costs.

The U.S. Environmental Protection Agency evaluated the ability of solar-powered circulation technology (SPC; Hudnell 2010a, b; Hudnell et al. 2010) to replace gridpowered aeration at four WWTPs (EPA 2005). SPC creates long distance circulation of the water column between the surface and the depth at which the radial intake hose is set (Hudnell et al. 2010). The Agency concluded that SPC reduced grid-powered aeration usage, grid-power consumption and operational costs, as well as odor events, sludge buildup and greenhouse gas emissions (EPA 2005). However, the Agency did not quantify electrical, water quality, or other parameters. The current study, directed by the New Hampshire Department of Environmental Services (NHDES), sought to quantify the effects of SPC on operational efficiency, water quality, odor events, and sludge thickness at three WWTPs.

Mixing improves processing efficiency by distributing DO and homogeneously blending total suspended solids (TSS) and dissolved wastewater constituents (EPA 2002a, b). Oxygenation supplies the DO required by bacteria to digest influent organic matter aerobically. Aerobic and facultative bacteria operating aerobically rapidly digest the organic matter when the biochemical oxygen demand (BOD) of the influent water is met (EPA 2002a, b). The digestion process yields water and carbon dioxide $\left(\mathrm{CO}_{2}\right)$, and reduces carbon concentration in the water when mixing promotes emission of the carbon dioxide to the atmosphere. Facultative bacteria operating anaerobically in the amorphous slurry near pond bottoms also digest organic matter, using oxygen supplied by nitrate $\left(\mathrm{NO}_{3}{ }^{-}\right)$and sulfate $\left(\mathrm{SO}_{4}^{-2}\right)$. This digestion process yields acids, alcohols, hydrogen sulfide $\left(\mathrm{H}_{2} \mathrm{~S}\right)$, and other toxic and malodorous sulfur compounds (Lyberatos and Skiadas 1999). Anaerobic bacteria beneath the slurry in the weight-bearing sludge ingest the acids and alcohols, producing carbon dioxide and methane $\left(\mathrm{CH}_{4}\right)$ through fermentation (Lyberatos and Skiadas 1999). Mixing promotes release of the carbon dioxide and methane to air, thereby further lowering carbon concentrations in the water. Maintaining oxygen in the top few centimeters or more of ponds provides an "odor cap" by oxidizing the malodorous sulfur compounds to odorless sulfate $\left(\mathrm{SO}_{4}{ }^{-2}\right)$.

Nitrogen from influent ammonium ions $\left(\mathrm{NH}_{4}{ }^{+}\right)$is released to air as elemental nitrogen gas $\left(\mathrm{N}_{2}\right)$ when nitrification is followed by denitrification. Autotrophic, nitrifying bacteria oxidize ammonium ions to nitrite $\left(\mathrm{NO}_{2}{ }^{-}\right)$, and further to nitrate, using DO for energy production and bicarbonates (forms of $\mathrm{HCO}_{3}{ }^{-}$) for cellular carbon (EPA $2002 \mathrm{~b}$ ). The rate of nitrification is highest at $\mathrm{pH}$ of about 7.5-9.0 and temperature of about $15-35^{\circ} \mathrm{C}$ (Shammas 1986). Denitrification primarily occurs when facultative bacteria oxidize organic matter in anaerobic areas of ponds. Heterotrophic, denitrifying bacteria reduce nitrate to nitrogen oxides (e.g., $\mathrm{NO}_{3}{ }^{-}, \mathrm{NO}_{2}{ }^{-}$), and ultimately nitrogen gas, during respiration. The rate of denitrification is highest at $\mathrm{pH}$ of about 7.5-8.5 and temperatures of about 25-35 ${ }^{\circ} \mathrm{C}$ (Zumft 1997). The nitrogen concentration in water declines as nitrogen gas is emitted to the atmosphere.

Grid-powered aeration consumes most of the electricity used in WWTPs (10 State Standards 1997). Approximately, $0.83 \mathrm{~kW}$ of power (equal to 1 horsepower assuming an electric motor efficiency of 92\%) for aeration is required to produce $0.9 \mathrm{~kg} \mathrm{DO} / \mathrm{h}$ (2 lbs DO/h; 10 State Standards 1997; Joint Task Force 1988). Each kilogram of influent BOD requires approximately $1.5 \mathrm{~kg}$ DO for digestion in extended aeration ponds (10 State Standards 1997). Approximately, $4.6 \mathrm{~kg}$ DO are required to convert $1 \mathrm{~kg}$ of ammonium ions to nitrate during nitrification, but most of this DO is recovered if denitrification follows nitrification in the same pond (Joint Task Force 1988). Power requirements for oxygenation and mixing are calculated separately, and the larger of the two, usually mixing, plus $15-20 \%$ excess capacity typically is installed (10 State Standards 1997).

Partial mix pond systems with 3-5 relatively large cells and 30-180 day detention times are the most common aerated pond systems in the U.S. Mixing requires approximately $\quad 10-12 \mathrm{~kW} / 3,785 \mathrm{~m}^{3} \quad(12-15 \mathrm{hp} / 1,000,000$ gal $)$ wastewater in the primary cell, and $5-6 \mathrm{~kW} / 3,785 \mathrm{~m}^{3}$ (6-8 hp/1,000,000 gal) wastewater in subsequent cells (Joint Task Force 1988). The power required for mixing is usually much greater than that required for oxygenation in partial mix systems (10 State Standards 1997; EPA 2002a).

Total mix systems, relatively uncommon in the U.S., were designed to eliminate the inefficiency caused by the imbalance of power needed for mixing and oxygenation. A small primary cell is generally sized to equalize the power needed for mixing and oxygenation at $25 \mathrm{~kW} / 3,785 \mathrm{~m}^{3}$ (30 hp/1,000,000 gal) wastewater (Joint Task Force 1988). The second cell is usually the last cell, and requires about $5 \mathrm{~kW} / 3,785 \mathrm{~m}^{3}$ (6 hp/1,000,000 gal) wastewater to suppress algae that could cause BOD and/or TSS permit violations (Joint Task Force 1988; Rich 1999). 
Waste sludge storage ponds, sometimes used in activated sludge systems, are usually aerated to provide an "odor cap" of $2 \mathrm{mg} / \mathrm{L}$ DO or more in the top 0.1-0.5 $\mathrm{m}$ to oxidize hydrogen sulfide and other malodorous sulfur compounds to odorless sulfate. Although algae and surface reaeration often supply the required DO, odor events can occur when aerobic digestion of dissolved organics in the upper water column depletes the DO. Odor events also may occur in unmixed ponds during seasonal turnovers when the sulfur compounds move with bottom water to the surface without passing through oxygenated water.

This report describes the water quality, odor control, sludge thickness, and kilowatt-hour (kWh) consumption and expenditure data 1 year prior to, and 2 years during, SPC treatment in the NHDES study at three WWTPs using aerated ponds in New Hampshire. SPC was expected to supply all required mixing and at least some of the required oxygen through surface reaeration at the air-to-water interface, and through entrainment of photosynthetically produced oxygen (EPA 2005).

\section{Methods}

Study goals and objectives

The goal of the NHDES study was to increase operational efficiency by reducing grid-power consumption at WWTPs while meeting National Pollutant Discharge Elimination System (NPDES) standards. Objectives of the studies were to monitor water quality parameters, malodorous events, and electricity consumption and expenditures for 1 year before, and 2 years during, SPC, and to monitor sludge and slurry thickness during the SPC-treatment period.

\section{Study sites}

The Water Department in the town of Pittsfield, New Hampshire, operates a secondary treatment plant using aerated ponds. The plant, built in 1977, consists of an open, earthen-impoundment pond divided into two cells by a curtain, and two additional earthen-impoundment cells (Fig. 1a). The final effluent is disinfected and dechlorinated prior to discharge to the Suncook River.

Parametric descriptions of the four cells are provided in Table 1. Prior to initiating SPC, Cells $1 \mathrm{a}$ and $1 \mathrm{~b}$ each used two $12.5 \mathrm{~kW}(15 \mathrm{hp})$ aerators $(50 \mathrm{~kW})$ continuously, whereas Cell 2 used two aerators of $5 \mathrm{~kW}(6 \mathrm{hp})$ each $(10 \mathrm{~kW})$ continuously, and Cell 3 used one $5 \mathrm{~kW}$ aerator continuously. The total power needed to operate the aerators was $65 \mathrm{~kW}$. Single SolarBee ${ }^{\circledR}$ SB10000 solar-powered circulation units were placed in Cells 1a and $1 \mathrm{~b}$, and single
SB2500 units were placed in Cells 2 and 3, shortly before SPC was initiated in April 2006 (Fig. 1a).

Effluent limits as issued by the NHDES through the NPDES were TSS: monthly mean $=30 \mathrm{mg} / \mathrm{L}$, weekly mean $=45 \mathrm{mg} / \mathrm{L}$, daily maximum $=50 \mathrm{mg} / \mathrm{L} ; \quad C B O D$ (carbon based BOD): monthly mean $=25 \mathrm{mg} / \mathrm{L}$, weekly mean $=40 \mathrm{mg} / \mathrm{L}$, daily $\operatorname{maximum}=45 \mathrm{mg} / \mathrm{L} ; \quad$ and $\mathrm{pH}=6.5-8.0 \mathrm{su}$ at all times. No NPDES limits were set for DO, ammonia or nitrate.

The Water and Sewer Department in the town of Exeter, New Hampshire, operates a secondary treatment plant using aerated ponds. The plant was built in 1965 and upgraded in 1990. Wastewater enters a grit chamber prior to processing in three open, earthen-impoundment ponds (Fig. 1b). The final effluent is disinfected and dechlorinated prior to discharge to the Squamscott River.

Parametric descriptions of the three cells are provided in Table 1. Prior to initiating SPC, 14 grid-powered mechanical aerators of $12.5 \mathrm{~kW}(15 \mathrm{hp})$ each $(175 \mathrm{~kW})$ provided continuous mixing and oxygenation in Cell 1, whereas Cell 2 used eight aerators of $6.65 \mathrm{~kW}(10 \mathrm{hp})$ each (53.2 kW) continuously, and Cell 3 used five aerators of $6.2 \mathrm{~kW}(7.5 \mathrm{hp})$ each $(31 \mathrm{~kW})$ continually. The total power needed to operate the aerators was $259.2 \mathrm{~kW}$. Two SolarBee $^{\circledR}$ SB10000 solar-powered circulators were placed in each of the three cells shortly before SPC was initiated in April 2006 (Fig. 1b).

Effluent limits were TSS and BOD: monthly mean $=30 \mathrm{mg} / \mathrm{L}$, weekly mean $=45 \mathrm{mg} / \mathrm{L}$, daily maximum $=50 \mathrm{mg} / \mathrm{L} ; \quad$ ammonia: summer (June-October) monthly and daily mean $=20.5 \mathrm{mg} / \mathrm{L}$, winter (NovemberMay) reporting required, but no limits set; and $\mathrm{pH}=6.5-8.0$ su at all times. No NPDES limits were set for DO or nitrate.

The Public Works Department in the City of Rochester, New Hampshire, operates an activated sludge, advanced tertiary-treatment plant. Three open, earthen-impoundment ponds were built in 1986 (Fig. 1c). The plant was converted from a pond-based system to an activated sludge system in 2000. Cells 1 and 2 were converted at that time from aerated raw septage and sludge storage ponds to sidestream, aerated, equalization basins. The third cell became the activated sludge reactor basin. The reactor basin effluent is disinfected with ultra violet light prior to discharge to the Cocheco River.

Parametric descriptions of the two equalization basins are provided in Table 1. Prior to initiating SPC, both cells were aerated continuously with a single $103.75 \mathrm{~kW}(125$ $\mathrm{hp)} \mathrm{positive} \mathrm{displacement} \mathrm{blower} \mathrm{connected} \mathrm{to} \mathrm{a} \mathrm{fine-}$ bubble tubing system. Impetus for the conversion to SPC was a scheduled $17 \%$ rate increase for grid power. Three SolarBee ${ }^{\circledR}$ SB10000 solar-powered circulators were placed in Cell 1, and two were placed in Cell 2, in April 2006 (Fig. 1c). The equalization basins received sludge from 

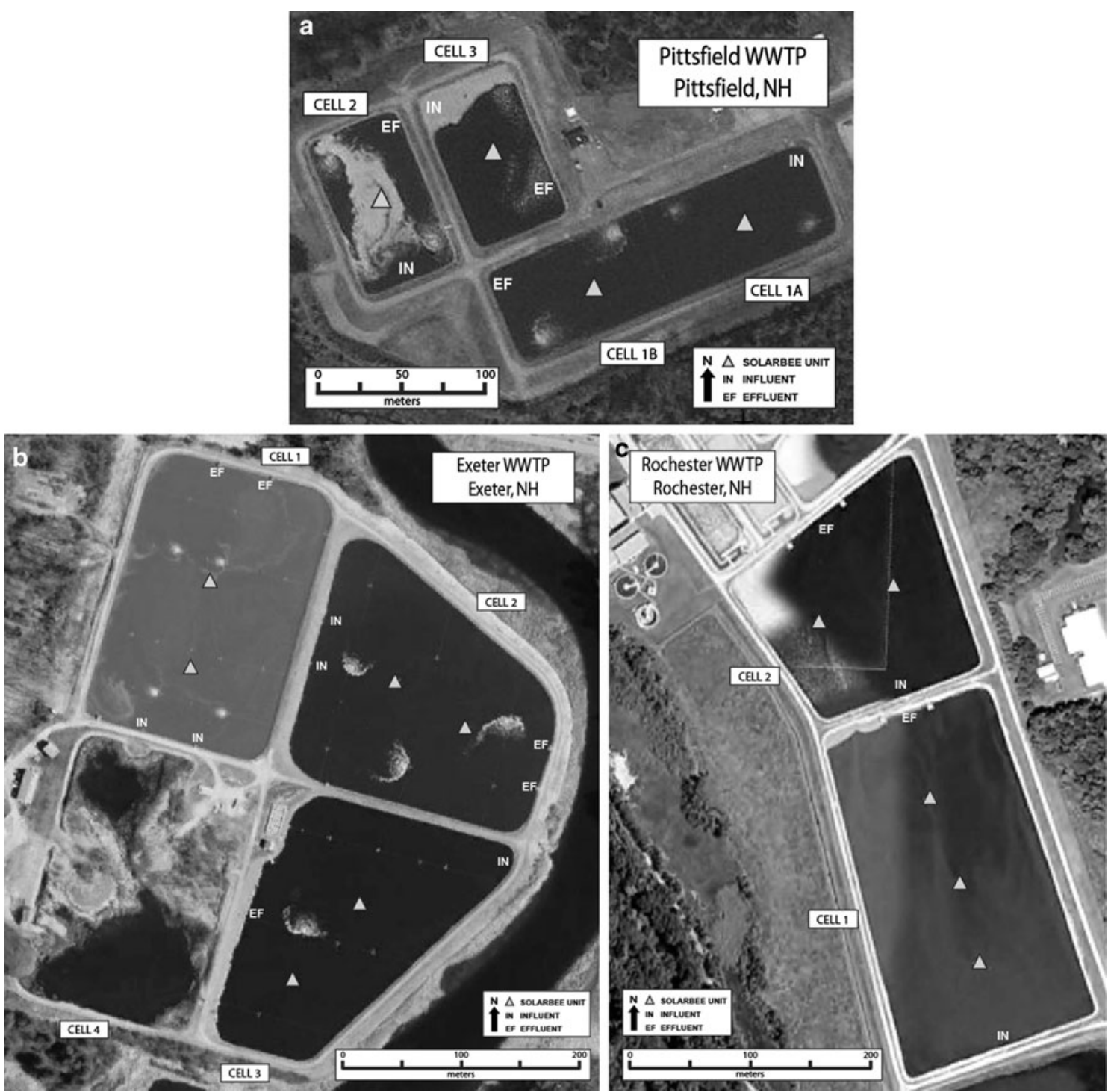

Fig. 1 Aerial photographs of the WWTP lagoons at Pittsfield (a), Exeter (b), and Rochester (c)

Cell 3, raw septage, equalization flow, filter backwash and raw sewage during the rainy season. In addition to the NHDES goals, goals at Rochester during SPC included: (1) elimination of all aeration usage; (2) DO levels sufficient to prevent odor events; (3) a reduced rate of sludge buildup and (4) 30-40\% BOD reduction before delivery of the effluent to the activated sludge reactor basin.

Effluent limits for TSS and BOD were: summer monthly mean $=6 \mathrm{mg} / \mathrm{L}$ and $114.3 \mathrm{~kg} / \mathrm{d}$, weekly mean $=6 \mathrm{mg} / \mathrm{L}$ and $114.3 \mathrm{~kg} / \mathrm{d}$, daily maximum $=9 \mathrm{mg} / \mathrm{L}$ and $171.5 \mathrm{~kg} / \mathrm{d}$, winter monthly mean $=13 \mathrm{mg} / \mathrm{L}$ and $247.7 \mathrm{~kg} / \mathrm{d}$, weekly mean $=13 \mathrm{mg} / \mathrm{L}$ and $400.1 \mathrm{~kg} / \mathrm{d}$, daily maximum $=$ $23 \mathrm{mg} / \mathrm{L}$ and $437.7 \mathrm{~kg} / \mathrm{d}$; ammonia: summer monthly mean $=3.61 \mathrm{mg} / \mathrm{L}$ and $68.9 \mathrm{~kg} / \mathrm{d}$, daily maximum $=$ $4.31 \mathrm{mg} / \mathrm{L}$ and $82.1 \mathrm{~kg} / \mathrm{d}$, and winter monthly mean = $7.65 \mathrm{mg} / \mathrm{L}$ and $145.6 \mathrm{~kg} / \mathrm{d}$, daily maximum $=26.30 \mathrm{mg} / \mathrm{L}$ and $500.8 \mathrm{~kg} / \mathrm{d}$; and $\mathrm{DO} \geq 7 \mathrm{mg} / \mathrm{L}$; and $\mathrm{pH}=6.5-8.0 \mathrm{su}$ at all times. No NPDES limits were set for nitrate.

Study design and measurement endpoints

The study used a paired-sample experimental design with pre- and during-SPC-treatment periods. The data were collected from April 2005 through March 2006 when gridpowered aeration was used exclusively (pre-SPC), and from April 2006 through March 2008 when SPC was supplemented by grid-powered aeration as needed to maintain DO at $\geq 2 \mathrm{mg} / \mathrm{L}$ (during-SPC) in Pittsfield and Exeter. No aeration was used in Rochester during the SPC study period.

The NHDES required measurements as specified in the NPDES permits, continuous measurement of influent and effluent flow into and out of the WWTPs, and daily recording 


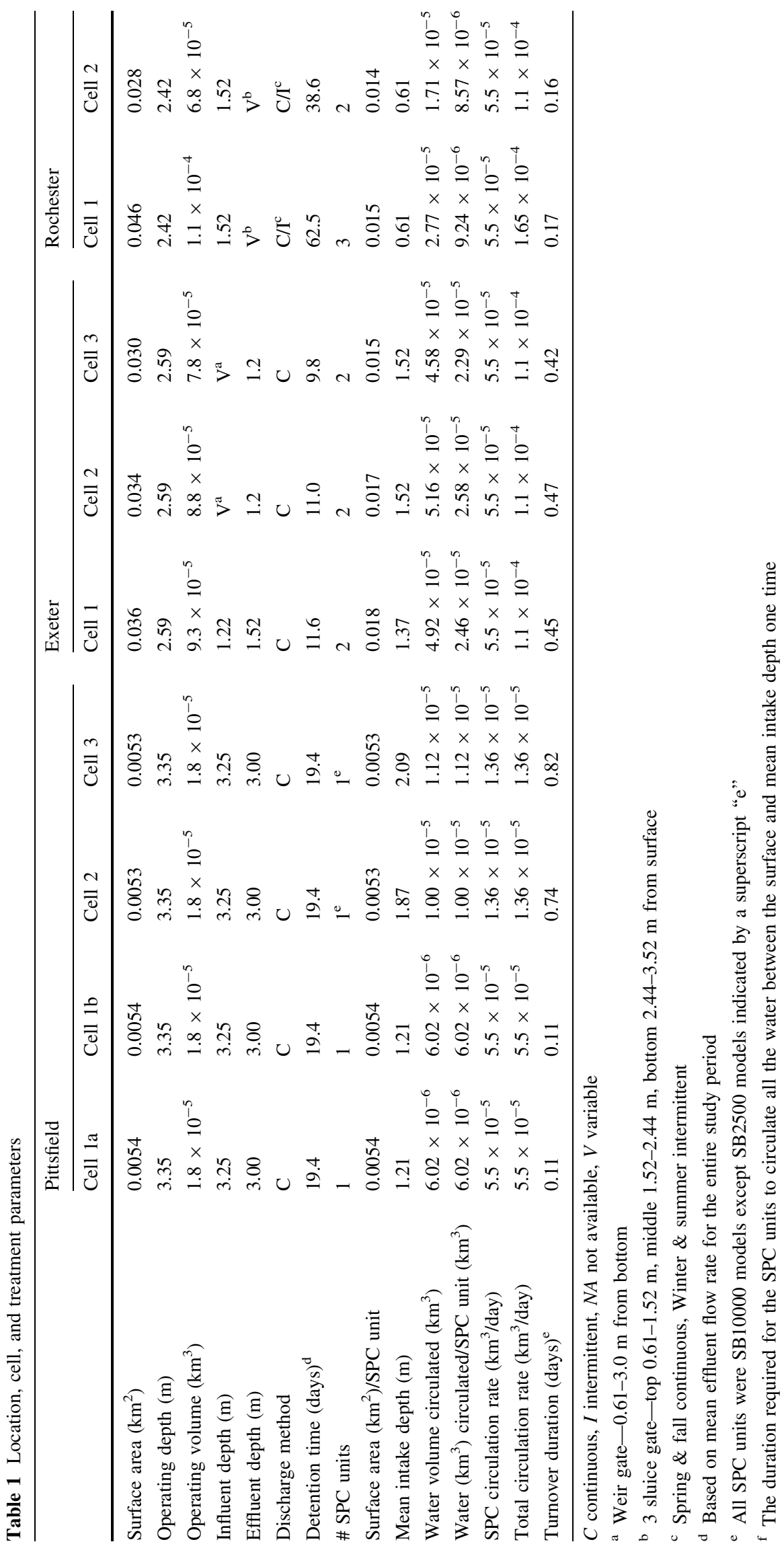


of climatic conditions throughout the two study periods. BOD, TSS, DO, and $\mathrm{pH}$ in final and treated cell effluents were measured weekly using standard methods (Eaton et al. 2005). Effluent ammonia and nitrate levels were measured as required in the NPDES permits or additionally at the discretion of the WWTPs, also using standard methods (Eaton et al. 2005). The NHDES also required that DO levels be maintained at $\geq 2 \mathrm{mg} / \mathrm{L}$ in each study cell. The raw data were converted into mean monthly values for this report.

Malodorous events were monitored continuously using olfactory perception and telemonitoring. All three WWTPs had potential for odor events because compounds such as hydrogen sulfide are produced through anaerobic digestion at the bottom of virtually all wastewater ponds.

Sludge and slurry thickness were measured at the beginning and end of the during-SPC study period, and once or twice per year during that study period. Weightbearing sludge and slurry layer thicknesses were measured at multiple locations in each cell using a standardized method (SolarBee 2008). Briefly, a $1723.7 \mathrm{~Pa}$ (0.25 psi)

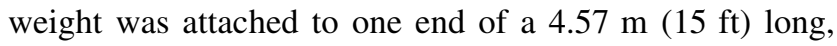
$6.35 \mathrm{~mm}(0.25 \mathrm{in})$ wide, braided PVC tubing with length delineations, whereas the other end was attached to a portable sampler pump with peristaltic head located in a boat. An additional tube attached to the pump discharged the sampled water. The weighted tubing was lowered until the sampled water suddenly changed color to dark brown, indicting the slurry top. The tubing was lowered farther until the weight was supported, indicating the top of the weight-bearing sludge, and then the entire procedure was repeated at least once. A pole with a blunt end and length delineations was forced through the sludge to the bottom of the cell, indicating the sludge bottom. The values measured at multiple locations were averaged to characterize conditions and monitor changes over time. The values for gridpower usage in $\mathrm{kWh}$ and cost were provided monthly by the electric utility.

\section{SPC technology}

Each SolarBee ${ }^{\circledR}$, Inc., SPC unit (Fig. 2) consisted of three pontoons that provided buoyancy for above water, near surface and underwater components (SolarBee 2010a). Solar panels, a low-voltage (originally $12 \mathrm{~V}$, now $18 \mathrm{~V}$ ), high-efficiency brushless (gearless) motor, a digital-electronic control box, and accessories were mounted on an above-water frame. A distribution dish, impeller and battery were suspended from the frame just below the surface. A $0.914 \mathrm{~m}$ diameter, flexible, intake hose was attached to the frame at the base of the impeller. A steel plate suspended $0.305 \mathrm{~m}$ beneath the hose intake caused water to be drawn in radially with near-laminar flow. Adjustments of

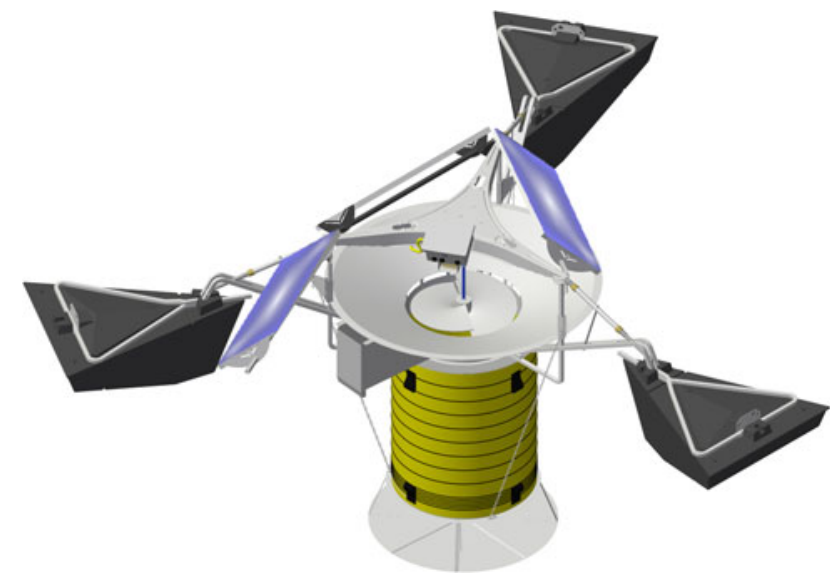

Fig. 2 An illustration of a SolarBee ${ }^{\circledR}$ SB10000v18 SPC unit with one of the solar panels rotated outward so the digital control box and motor housing can be seen

chains attached to the plate and frame controlled intake depth. Additional chains attached to the frame and two moorings maintained the spatial position of the unit. The battery powered the motor to rotate the impeller at $60-80$ RPM (all newer, and most older, units now rotate at 80 RPM) $24 \mathrm{~h} /$ day, 7 days/week. If prolonged periods of low light incidence caused the battery charge to fall below $60 \%$, the electronic controller switched on grid-power to charge the battery. The units transported approximately $37,850 \mathrm{~L} / \mathrm{min}$ of water to the surface (Ohio EPA 2004; San Francisco 2004; JVA 2006; Hudnell 2009). Approximately, $11,355 \mathrm{~L} / \mathrm{min}$ of direct flow ascended through the hose, and another $26,495 \mathrm{~L} / \mathrm{min}$ of induced flow ascended external to the hose. Water departed radially from the units without turbulence, both above and below the distribution dish. The outflow mixed with other surface currents to redistribute water across the treatment area. The units were designed for low maintenance (SolarBee 2010b) and a 25-year lifetime (SolarBee 2010c).

\section{Statistical analyses}

All descriptive and inferential statistical procedures were performed using Microsoft ${ }^{\circledR}$ Excel $^{\circledR} 2008$ for Mac, Version 12.2.3. Average values and variances are reported as the mean \pm the standard deviation of population samples. The pre- versus during-SPC comparisons were assessed for statistically significant differences using two-tailed, equal variance, Student's $t$ tests with $\alpha=0.05$. Correlations between variables were assessed by deriving Pearson correlation coefficients, and tested for significance using a table of critical values for the Pearson product moment correlation coefficient for two-tailed tests with $\alpha=0.05$. 


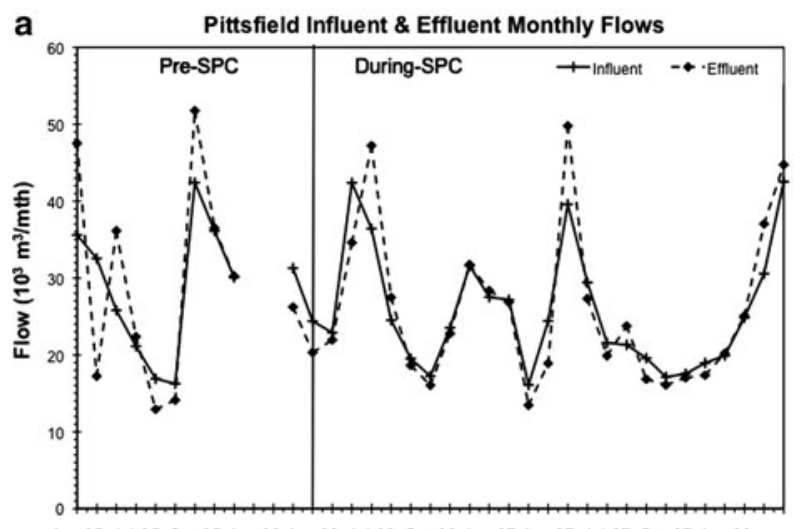

Apr-05 Jul-05 Oct-05 Jan-06 Apr-06 Jul-06 Oct-06 Jan-07 Apr-07 Jul-07 Oct-07 Jan-08

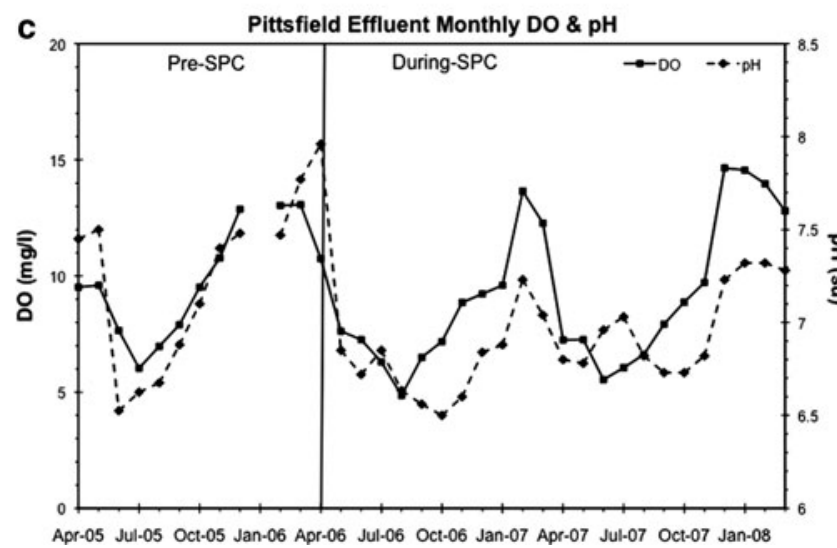

Fig. 3 Data collected at the Pittsfield WWTP during the study, April 2005 to March 2008. The SB10000 SPC units operated continuously in Cells 1a and $1 \mathrm{~b}$ during the SPC study period, and grid-powered aeration was used intermittently to increase DO concentrations. Usage of the smaller SB2500 units in Cells 2 and 3 was discontinued in June 2007, whereas grid-powered aeration usage was increased (see "Discussion" section). Mean monthly influent and effluent water volumes were comparable during the pre- and during-SPC study periods (a). Effluent TSS and CBOD levels were significantly

\section{Results}

Pittsfield, a partial mix pond system

Water flow and quality parameters showed no statistically significant differences between the pre- and during-SPCtreatment periods at the Pittsfield WWTP, and no NPDES violations occurred during either study period. Pre- and post-SPC mean monthly influent flow rates were $28.5 \pm 9.1$ and $25.8 \pm 7.7 \quad 10^{3} \mathrm{~m}^{3} / \mathrm{mth} \quad(P>0.05)$, respectively, whereas corresponding effluent flow rates were $29.9 \pm 14.3$ and $25.8 \pm 9.910^{3} \mathrm{~m}^{3} / \mathrm{mth}(P>0.05$, Fig. 3a). Pre- and during-SPC mean monthly levels were similar: $15.1 \pm 8.0$ and $14.2 \pm 8.3 \mathrm{mg} / \mathrm{L}(P>0.05)$ for TSS, and $7.8 \pm 4.0$ and $10.7 \pm 6.8 \mathrm{mg} / \mathrm{L}(P>0.05)$ for CBOD, respectively (Fig. 3b). TSS and CBOD levels varied together in similar patterns before and during SPC
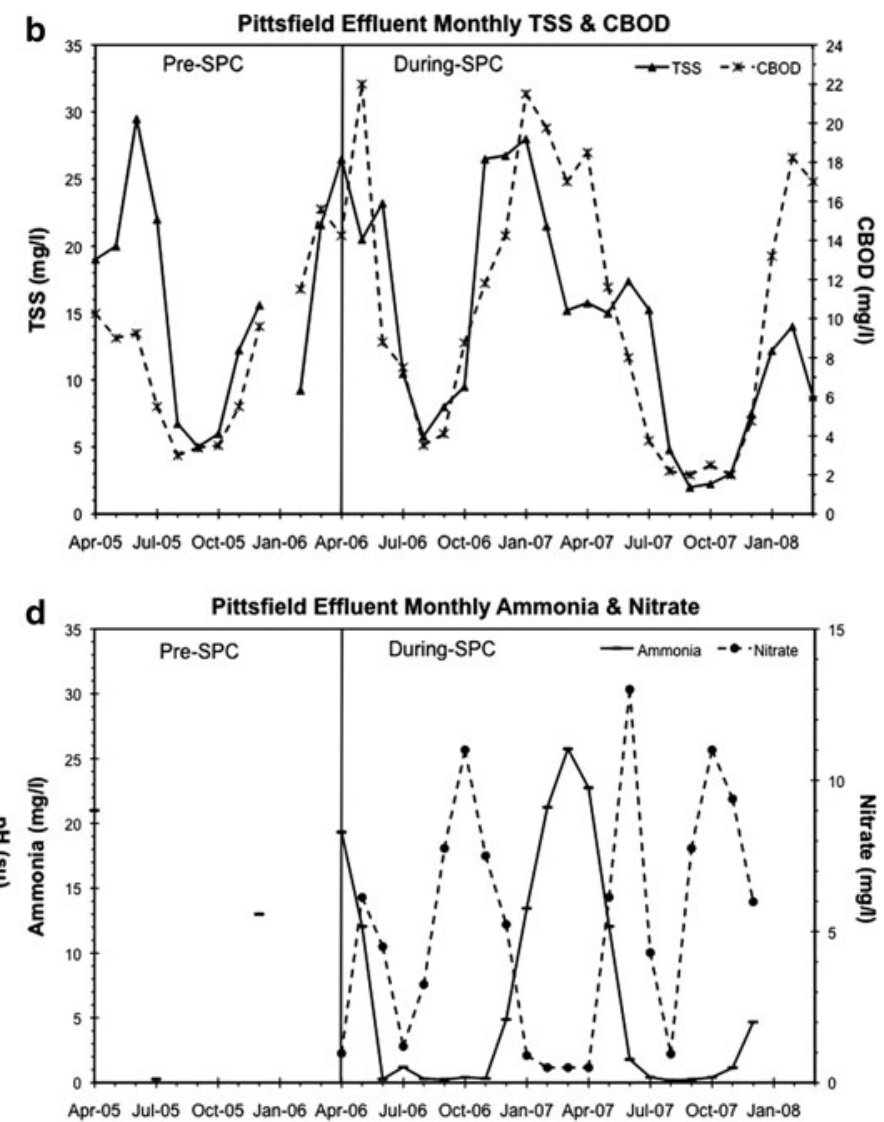

associated, and varied with yearly seasons during both study periods (b). Similar seasonal variations were observed in effluent $\mathrm{DO}$ and $\mathrm{pH}$ concentrations (c). Effluent ammonia concentrations also showed a similar seasonal variation, and were significantly and inversely associated with effluent nitrate concentration (d). Although pre-SPC ammonia concentration was measured only in April, July, and December, concentrations were similar to those observed during the same months in the during-SPC study period

( $r=0.62, P<0.05$ ); maximum levels generally occurred during late winter and spring, whereas minima were observed during late summer and fall. $\mathrm{DO}$ and $\mathrm{pH}$ ( $r=0.70, P<0.05$ ) showed seasonal variations similar to those of TSS and CBOD (Fig. 3c), and DO concentration was associated with CBOD level $(r=0.44, P<0.05)$, but not with TSS $(r=0.06, P>0.05)$. Pre- and during-SPC mean monthly levels did not differ significantly for DO, $9.7 \pm 2.5$ and $9.1 \pm 3.0 \mathrm{mg} / \mathrm{L} \quad(P>0.05)$, or $\mathrm{pH}$, $7.2 \pm 0.4$ and $6.9 \pm 0.3 \mathrm{su}(P>0.05)$. Ammonia concentrations (Fig. 3d) also varied seasonally in a pattern similar to TSS $(r=0.80, r<0.05)$ and CBOD $(r=0.45$, $P<0.05)$, were positively correlated with DO $(r=0.52$, $P<0.05)$ and $\mathrm{pH}(r=0.54, P<0.05)$, and varied inversely with nitrate levels $(r=-0.60, P<0.05)$. Few ammonia, and no nitrate, measures were collected during the pre-SPC study period, but the available pre-SPC 

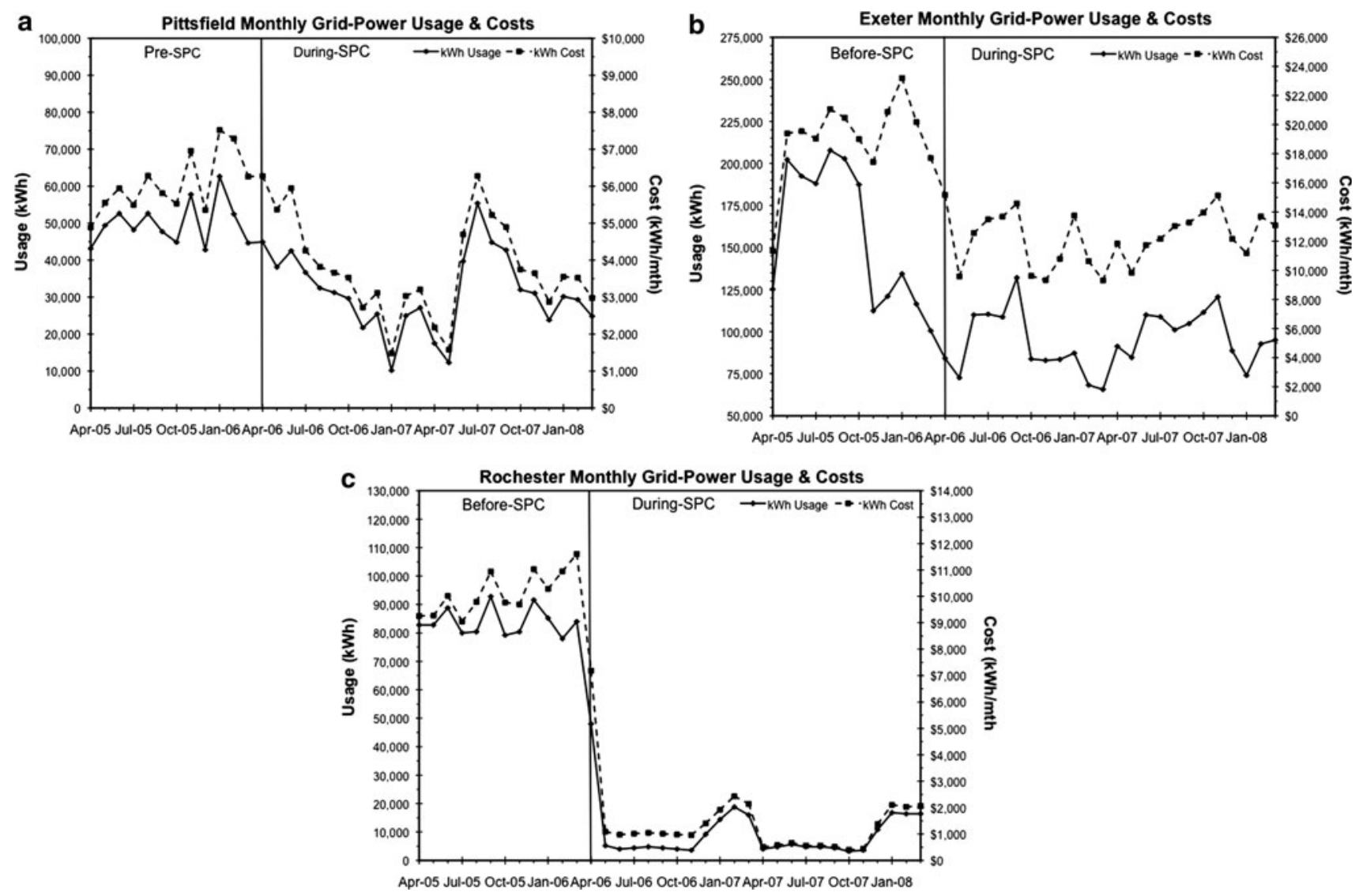

Fig. 4 Electrical power consumption and expenditures at the three study sites during the pre- and during-SPC study periods. Consumption and expenditures decreased during SPC by about 38 and $37 \%$, respectively, resulting in a 3.7 year pay back period, at Pittsfield (a). The usage and cost increase beginning in June 2007 reflects the removal of the SPC units from Cells 2 and 3 and increased aeration in those cells to reduce algal density and maintain DO $>2 \mathrm{mg} / \mathrm{L}$. Consumption and expenditures decreased during SPC by about 40 and

ammonia measures indicated a pattern similar to that observed during SPC (Fig. 3d). Mean monthly ammonia concentration was $6.8 \pm 8.8 \mathrm{mg} / \mathrm{L}$, and mean monthly nitrate concentration was $5.2 \pm 3.9 \mathrm{mg} / \mathrm{L}$, during-SPC.

Malodorous events were not experienced at any time during the study, but were experienced occasionally prior to the study. Sludge was removed from the cells a few months before study commencement. Changes in sludge thickness during SPC were: Cell 1a $=-0.02 \mathrm{~m}$; Cell 1b $=+0.13 \mathrm{~m}$; Cell $2=+0.12 \mathrm{~m}$ and; Cell $3=+0.10 \mathrm{~m}$. Changes in combined sludge and slurry thickness were: Cell $1 \mathrm{a}=$ $+0.04 \mathrm{~m}$; Cell $1 \mathrm{~b}=+0.19 \mathrm{~m}$; Cell $2=+0.19 \mathrm{~m}$ and; Cell $3=+0.20 \mathrm{~m}$.

Grid power usage and expenditures before and during SPC are shown in Fig. 4a. Mean monthly usage and expenditure decreased during SPC by $18,712 \mathrm{kWh}$ and $\$ 2,256$, respectively. Annualized usage declined by $224,540 \mathrm{kWh}$, and annualized expenditure decreased by
$36 \%$, respectively, resulting in a 2.9 year pay back period, at Exeter (b). Comparable figures in Rochester were 89 and $86 \%$, respectively, resulting in a 1.9 year pay back period (c). The Rochester data do not include electricity used for diffused bubble aeration in Cell 3, the activated sludge reactor basin. The decreased spread between usage and cost at Pittsfield and Rochester during SPC was due to $\mathrm{kWh}$ rate decreases when usage declined

$\$ 27,068$, resulting in a payback period of 3.7 years for the two SPC units in Cells 1a and 1b. Use of the smaller SPC units in Cells 2 and 3 was discontinued in June 2007, and the usage of grid-powered aeration was increased in these cells. Those two units were returned to SolarBee, Inc., for reasons described in the "Discussion" section.

Exeter, a partial mix pond system

Water flow and quality at the Exeter WWTP were similar during the pre- and during-SPC study periods, and no NPDES violations occurred during either study period. The pre- and during-SPC mean monthly effluent flow rates were comparable at $250.9 \pm 80.410^{3} \mathrm{~m}^{3} / \mathrm{mth}$, and $229.3 \pm 94.0$ $10^{3} \mathrm{~m}^{3} / \mathrm{mth}(P>0.05)$ during the two study periods. Mean monthly TSS, BOD, $\mathrm{pH}$ and ammonia levels during SPC, $17.9 \pm 7.0 \mathrm{mg} / \mathrm{L}, \quad 14.4 \pm 6.4 \mathrm{mg} / \mathrm{L}, \quad 7.0 \pm 0.3 \mathrm{su}, \quad$ and $10.4 \pm 6.9 \mathrm{mg} / \mathrm{L}$, did not differ significantly $(P>0.05)$ 


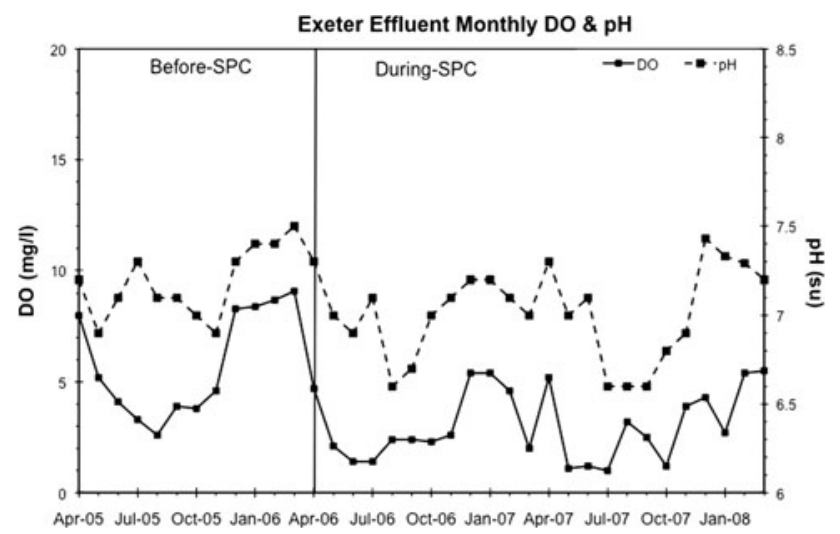

Fig. 5 Mean monthly effluent DO and $\mathrm{pH}$ concentrations at Exeter during the pre- and during-SPC study periods. Mean monthly DO concentration was significantly lower during SPC, whereas water quality outcomes were comparable. These results indicated that DO concentration was excessive during the pre-SPC study period due to the use of aeration for mixing

from the levels observed before SPC, $12.7 \pm 7.9 \mathrm{mg} / \mathrm{L}$, $12.0 \pm 4.7 \mathrm{mg} / \mathrm{L}, \quad 7.2 \pm 0.2 \mathrm{su}, \quad$ and $\quad 9.9 \pm 4.9 \mathrm{mg} / \mathrm{L}$, respectively. Pre- and during-SPC mean monthly removal efficiencies for TSS were 89 and $87 \%$, and for BOD 89 and $90 \%$, respectively. TSS and BOD levels varied together less closely than at Pittsfield $(r=0.40, P<0.05)$ and seasonal trends were less pronounced. The mean monthly DO level during SPC, $3.1 \pm 1.6 \mathrm{mg} / \mathrm{L}$, was significantly lower $(P<0.05)$ than the pre-SPC level of $5.8 \pm 2.4 \mathrm{mg} / \mathrm{L}$ (Fig. 5). DO concentration was significantly correlated only with $\mathrm{pH}(r=0.64, P<0.05$; Fig. 5), a potential indication of carbon dioxide consumption and oxygen production by algae during photosynthesis. Mean monthly $\mathrm{pH}$ was $7.2 \pm 0.2$ su before SPC and $7.0 \pm 0.3$ su during SPC $(P>0.05)$, and was significantly associated with ammonia levels throughout the study $(r=0.75, P<0.05)$. Ammonia concentrations showed a seasonal pattern similar to that observed at Pittsfield (Fig. 5). Mean monthly ammonia concentration prior to SPC, $9.3 \pm 4.9 \mathrm{mg} / \mathrm{L}$, was statistically the same as that observed during SPC, $10.4 \pm 6.9 \mathrm{mg} / \mathrm{L}$, $P>0.05$. Nitrate concentrations were not measured.

Malodorous events were not experienced at any time during the study, but were experienced periodically prior to the study. Mean sludge depths increased by approximately $0.20 \mathrm{~m}$ in Cell 1, decreased by about $0.34 \mathrm{~m}$ in Cell 2, and increased by about $0.09 \mathrm{~m}$ in Cell 3 during the SPC study period. Corresponding mean sludge and slurry thickness changes were $+0.23,+0.05$, and $+0.07 \mathrm{~m}$.

Grid power usage and expenditures before and during SPC are shown in Fig. 4b. Mean monthly usage and expenditure decreased during SPC by $62,896 \mathrm{kWh}$ and $\$ 6,876$, respectively. Annualized usage declined by $754,753 \mathrm{kWh}$, and annualized expenditure decreased by $\$ 82,513$, resulting in a payback period of 2.9 years for the six SPC units.

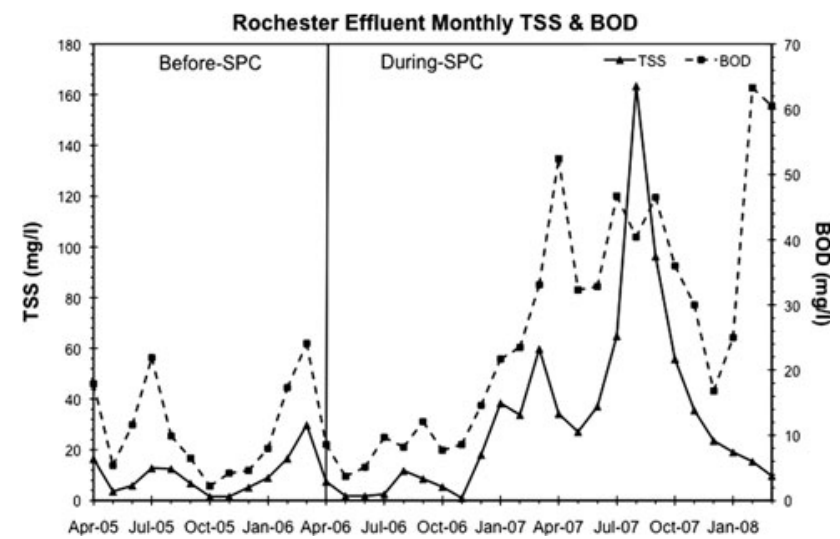

Fig. 6 Mean monthly equalization basin effluent TSS and BOD levels at Rochester during the pre- and during-SPC study periods. Both TSS and BOD levels were significantly higher in the equalization basin effluent during-SPC. BOD and TSS levels increased during Year Two of treatment when raw septage and sewage inputs reached record-high levels. An algal bloom and zooplankton population expansion in August 2007 also increased TSS level. TSS and BOD levels declined by $30-40 \%$ in the equalization basins during SPC, before transfer to the activated sludge reactor basin, where the TSS and BOD effluent levels were statistically the same during the two study periods

Rochester, an activated sludge system

Water flow and quality at the Rochester WWTP were similar during the pre- and during-SPC study periods, and no NPDES violations occurred during either study period. The pre- and during-SPC mean monthly effluent flow rates were comparable at $1,775.8 \pm 796.2 \mathrm{~m}^{3} / \mathrm{mth}$ and $1,737.1 \pm 717.7 \mathrm{~m}^{3} / \mathrm{mth} \quad(P>0.05)$, respectively. The TSS and BOD levels in Cells 1 and 2 effluent increased significantly during SPC (Fig. 6), but were statistically the same in the final effluent from Cell 3. Pre- and duringSPC mean monthly levels were $10.2 \pm 8.1$ and $32.2 \pm 36.8 \mathrm{mg} / \mathrm{L}(P<0.05)$ for TSS, and $11.1 \pm 7.4$ and $26.6 \pm 18.0 \mathrm{mg} / \mathrm{L} \quad(P<0.05)$ for $\mathrm{BOD}$, respectively. Removal efficiencies for TSS and BOD before transfer to Cell 3, the activated sludge reactor basin, ranged from 30 to $40 \%$ during SPC. The TSS and BOD levels varied together in similar patterns before and during SPC $(r=0.55$, $P<0.05)$. Statistically significant differences between the pre- and during-SPC periods were not observed $(P>0.05)$ for $\mathrm{DO}, \quad 4.7 \pm 2.1 \mathrm{mg} / \mathrm{L}$ vs. $4.3 \pm 2.4 \mathrm{mg} / \mathrm{L}, \quad \mathrm{pH}$, $7.6 \pm 0.3$ vs. $7.5 \pm 0.2 \mathrm{su}$, or ammonia, $13.5 \pm 7.1$ and $16.7 \pm 8.8 \mathrm{mg} / \mathrm{L}$. TSS and BOD were not significantly correlated with $\mathrm{DO}, \mathrm{pH}$, or ammonia $(P>0.05)$.

Malodorous events were not experienced at any time during the study. Mean sludge depths increased by approximately $0.16 \mathrm{~m}$ in both Cells 1 and 2 during SPC. Corresponding mean sludge and slurry thickness changes were +0.17 and $+0.05 \mathrm{~m}$. Operations personnel deemed 
these sludge accumulation rates to be significantly less than those of the pre-SPC study period, but objective indicators were not available. The sludge depths were reported to have stabilized since the study was completed.

Grid power usage and expenditures before and during SPC are shown in Fig. 4c. Mean monthly usage and expenditure decreased during SPC by $74,150 \mathrm{kWh}$ and $\$ 8,722$, respectively. Portions of the decreases were due to reclassification to a lower rate schedule as usage dropped precipitously. Annualized usage declined by $889,803 \mathrm{kWh}$, and annualized expenditure decreased by $\$ 104,658$, resulting in a payback period of 1.9 years for the five SPC units.

\section{Discussion}

Grid power consumption fell sharply when SPC supplied the mixing and at least part of the oxygenation previously obtained through aeration. Final effluent water quality was maintained, no NPDES violations or odor events occurred, and sludge buildup was minimal during the SPC study period. Electricity usage and cost declined during SPC at the partial mix pond systems at Pittsfield (by 37.5 and $37.2 \%$, respectively), and Exeter (by 40.0 and 36.0\%, respectively). The termination of all aeration in Rochester's equalization basins at the start of the during-SPC period reduced electricity usage by $88.5 \%$ and cost by $86.0 \%$. The NHDES goal of increasing operational efficiency while meeting NPDES standards was achieved. Grid-power consumption, associated greenhouse gas emissions, and operational costs decreased without compromising water quality, and resulted in carbon dioxide emission reductions of 273,161, 918,183, and 1,082,509 kg at Pittsfield, Exeter, and Rochester, respectively $(1 \mathrm{kWh}$ generation $=0.608 \mathrm{~kg}$ carbon dioxide emission, DOE \& EPA 2000).

The Pittsfield data demonstrated a strong positive association between TSS and CBOD concentrations with maxima in late winter and spring, and minima in late summer and fall. High algal (i.e., chlorophyta) densities in the effluent, often observed in pond systems, may have partially caused the association. DO and $\mathrm{pH}$ levels, also expected to increase with algal density, increased with CBOD. The strong, negative correlation between ammonia and nitrate concentrations indicted that the rate of nitrification increased during warmer months and decreased during cooler months.

SPC was terminated in Pittsfield Cells 2 and 3 in June 2007. Aeration was used extensively from June through September 2007 to reduce algal density, resulting in the increased grid power consumption and cost shown in Fig. 4a. Aeration was used throughout the remainder of the
during-SPC study period as needed to control algae and maintain DO concentration above $2 \mathrm{mg} / \mathrm{L}$. Pittsfield WWTP personnel concluded that operational efficiency was best when SPC units were used in Cells 1a and 1b, and aeration used in Cells 2 and 3.

The TSS and BOD association was positive and significant in Exeter, but weaker and less seasonally related than that observed in Pittsfield. The strong $\mathrm{pH}$ and ammonia correlation may indicate that nitrification of ammonia drove down both the ammonia and $\mathrm{pH}$ levels as alkalinity was consumed. The positive and significant association between DO and $\mathrm{pH}$ likely indicates that algae produced a substantial proportion of the oxygen when $\mathrm{pH}$ was elevated. The maintenance of good water quality while DO levels were significantly lower during SPC (Fig. 5) indicated that more aeration was needed for mixing than for DO supply during the before-SPC study period.

The positive association between TSS and BOD was the only significant correlation among water quality parameters at the Rochester plant after aeration was terminated and SPC initiated in Cells 1 and 2. Record high raw septage and sewage inputs to the equalization basins, recorded during the second half of the during-SPC study period (data not shown), contributed to the significant increases in both parameters during SPC. Algae (i.e., chlorophyta) also increased TSS; an algal bloom followed by an expansion of the zooplankton population was observed during the TSS peak in August 2007 (Fig. 6). The equalization basins prepared effluent to enter the activated sludge reactor basin by achieving a 30-40\% reduction of influent BOD throughout the during-SPC study period.

The objective of providing enough oxygen in the top $0.1-0.5 \mathrm{~m}$ of the water column to oxidize malodorous and potentially toxic sulfur compounds to odorless and relatively nontoxic sulfate was met at all three plants during the SPC study period. Little or no sludge accumulated in the study ponds during the SPC period.

Circulating water above the slurry in facultative and partial-mix ponds improves sludge digestion through methane and carbon dioxide formation in two ways. First, facultative bacteria operating anaerobically digest organics in the slurry, producing water, alcohols, and acids (MataAlvarez et al. 2000). Anaerobic bacteria in the sludge beneath the slurry utilize the alcohols and acids, producing carbon dioxide and methane gas through fermentation only when the $\mathrm{pH}$ is 6.2 or higher (EPA 1976). Mixing the upper water column with SPC, as opposed to grid-powered aeration, increases $\mathrm{pH}$ by increasing algal (i.e., chlorophyta) densities (Hudnell et al. 2010). The algae increase $\mathrm{pH}$ by consuming $\mathrm{CO}_{2}$ during photosynthesis. The higher $\mathrm{pH}$ water diffuses into the slurry layer, neutralizing some of the acids produced during anaerobic digestion. Neutralizing the acids prevents the $\mathrm{pH}$ from dropping to levels that 
inhibit activity of the methane-forming bacteria (EPA 2006). Second, mixing the upper portion of the water column eliminates the neuston layer of lipids and proteins floating on the surface (Eaton et al. 2005). Methane and carbon dioxide are more easily release from water to air without the neuston cap. As methane concentration in water decreases, anaerobic bacteria increase methane formation rate and sludge digestion (Thiel 1969). Methane and carbon dioxide emissions to the atmosphere reduce carbon concentration and sludge thickness.

\section{Conclusion}

The traditional use of grid-powered, mechanical aeration to both mix and oxygenate wastewater ponds causes an operational inefficiency. The current study demonstrated that SPC provides ample mixing and a substantial proportion of the oxygen needed to produce high quality effluent. The use of SPC reduced the need to use aeration, resulting in decreased grid-power consumption and expenditures, and associated greenhouse gas emissions. Expenditures for grid power at the two pond-based treatment plants decreased by approximately $37 \%$. The cost savings on grid power equaled the expenditures on SPC implementation in 2.9 years at Exeter and 3.7 years at Pittsfield. Much larger efficiency gains were seen at the Rochester activated sludge treatment plant where two equalization basins terminated aeration when SPC was initiated. Expenditures for grid power decreased by $86 \%$, savings that equaled the cost of SPC implementation in 1.9 years. The 25-year expected lifetime of SPC units with minimal maintenance requirements (SolarBee 2010a, b) indicates a long-term reduction in operational expenses.

Acknowledgments The authors gratefully acknowledge and thank Lacey Kupper and Kristy Hintz for the many hours they spent producing graphics for this study and article.

Conflict of interest statement The utility-employee coauthors of this article declare that they have no conflicts of interest concerning this study or article. SolarBee, Inc., the company that developed and manufactures SPC technology, employs the other coauthors.

Open Access This article is distributed under the terms of the Creative Commons Attribution Noncommercial License which permits any noncommercial use, distribution, and reproduction in any medium, provided the original author(s) and source are credited.

\section{References}

DOE \& EPA (2000) Carbon dioxide emissions from the generation of electric power in the United States. Department of Energy and Environmental Protection Agency, Washington, D.C. http://www. eia.doe.gov/electricity/page/co2_report/co2report.html. Accessed 18 Oct 2010

Eaton AD, Clesceri LS, Rice EW, Greenberg AE, Franson MA (eds) (2005) Standard methods for the examination of water and wastewater, 21st edn. American Public Health Association, American Water Works Association, Water Environment Federation [Joint publishers], $1368 \mathrm{pp}$

EPA (1976) Anaerobic sludge digestion. Office of Water, EPA 430/976-001. http://nepis.epa.gov. Accessed 18 October 2010

EPA (2002a) Wastewater technology fact sheet: aerated, partial mix lagoons. Office of Water, EPA 832-F-02-008. http://www.epa. gov/owm $/ \mathrm{mtb} / \mathrm{mtbfact} . \mathrm{htm}$. Accessed 18 October 2010

EPA (2002b) Nitrification. Prepared by AWWA with assistance form Economic and Engineering Services, Inc. http://www.epa.gov/ safewater/disinfection/tcr/pdfs/whitepaper_tcr_nitrification.pdf. Accessed 18 October 2010

EPA (2005) Auxiliary and supplemental power fact sheet: solar power. Office of water, EPA 832-F-05-011, revised 2007. http:// www.epa.gov/owm/mtb/mtbfact.htm. Accessed 18 October 2010

EPA (2006) Biosolids technology fact sheet. Office of water, EPA 832-F-06-031. http://www.epa.gov/OW-OWM.html/mtb/multistage.pdf. Accessed 18 October 2010

Hudnell HK (2009) Mixing, de-stratification, and break-point chlorination in San Francisco's sunset reservoir. White Paper. http://science.solarbee.com/white-papers. Accessed 18 October 2010

Hudnell HK (2010a) The state of U.S. freshwater harmful algal bloom assessments, policy and legislation. Toxicon 55:1024-1034

Hudnell HK (2010b) Within water-body management: a needed but neglected complement to watershed management. Clean Technol Environ Policy 12:205-207

Hudnell HK, Jones C, Labisi B, Lucero V, Hill DR, Eilers J (2010) Freshwater harmful algal bloom (FHAB) suppression with solar powered circulation (SPC). Harmful Algae 9:208-217

Joint Task Force (1988) Aeration, a wastewater treatment process. WPCF-Manual of Practice-FD-13, ASCE-Manuals and Reports on Engineering Practice-No. 68. Prepared by a Joint Task Force of the Water Pollution Control Federation and American Society of Civil Engineers, 178 pp, ISBN 0-87262-673-3.

JVA (2006) Town of Bennett-Phase II WWTP Improvement-New Technology Review for Solar Bee Mixers. JVA, Inc., Fort Collins, Colorado. http://wastewater.solarbee.com/customerverification. Accessed 18 October 2010

Lyberatos G, Skiadas IV (1999) Modelling of anaerobic digestion-a review. Global Nest Int J 1:63-76. http://www.gnest.org/ Journal/journal.htm. Accessed 18 October 2010

Mata-Alvarez J, Mace S, Liabres P (2000) Anaerobic digestion of organic solid waste. An overview of research achievements and perspectives. Bioresour Technol 74:3-16

Ohio EPA (2004) SolarBee SB10000W Pond re-circulating pump evaluation. Rockford, Ohio. http://wastewater.solarbee.com/ customer-verification. Accessed 18 October 2010

Rich LG (1999) High performance aerated lagoon systems. American Academy of Environmental Engineers, Annapolis, MD, 216 pp, ISBN 883767-27-X.

San Francisco (2004) SolarBee mixer study: sunset reservoir South Basin. San Francisco Public Utility Commission, San Francisco, California. http://potablewater.solarbee.com/node/538. Accessed 18 October 2010

Shammas HK (1986) Interaction of temperature, $\mathrm{pH}$ and biomass on the nitrification process. J Water Pollut Contr Fed 58:52-59

SolarBee (2008) Sludge testing in ponds. Sludge 20080324, 3 pp. http://wastewater.solarbee.com/literature-downloads. Accessed 18 October 2010

SolarBee (2010a) SolarBee technology. http://www.solarbee.com/ solarbee-machine-technology. Accessed 18 October 2010 
SolarBee (2010b) SolarBee technology: low maintenance design. http://www.solarbee.com/solarbee-machine-technology/lowmaintenance-design. Accessed 18 October 2010

SolarBee (2010c) SolarBee technology: motor and drive system. http://www.solarbee.com/solarbee-machine-technology/motorand-drive-system. Accessed 18 October 2010

10 State Standards (1997) Recommended standards for wastewater facilities. A report of the wastewater committee of the Great
Lakes-Upper Mississippi River; Board of state and provincial public health and environmental managers. Health Research, Inc., Albany, New York, 152 pp. http://10statesstandards.com/ wastewaterstandards.html. Accessed 18 October 2010

Thiel PG (1969) The effect of methane analogues on methanogenesis in anaerobic digestion. Water Res 3:215-223

Zumft WG (1997) Cell biology and molecular basis of denitrification. Microbiol Mol Biol Rev 61:533-616 